\section{My total hip replacement}

\author{
Louise Grant
}

\section{IN THE BEGINNING}

My mother had a total hip replacement (THR) 20 years ago, at age 50, just after my dad had died of a brain tumour. She would say, 'at least this hip problem is not life threatening'. After mum's joint replacement surgery, I saw her live life to the full-including jet-skiing, tandem paragliding! Her replaced hip (the early small-headed Charnley prosthesis) is still doing great. As a young physiotherapist, I wanted to learn all I could to help mum's hip stand the test of time and that is where my journey started as a hip specialist physiotherapist in the UK.

My first time as a hip patient was in 2011, after 20 years of treating hip patients (figure 1). I had an accident slipping on some ice and badly tore my left hip labral cartilage. I underwent a hip arthroscopy which after 9 months of tailored graded rehabilitation successfully relieved my pain, muscle inhibition and joint stiffness-it gave me my life back.

Having a hip injury and recovering from the hip arthroscopy gave me valuable insight into how having hip pain can affect you physically and mentally, and how addressing both aspects is equally important. ${ }^{1}$ My experience really helped me understand my patients better; some of my colleagues and patients joked that I had it done as a learning experience to show my true dedication to my practice! In truth I tried everything first ${ }^{2}$ - I had addressed every muscle weakness, postural and movement pattern and mental health component before I took the surgical option. Surgery scared me as I knew the risks and complications only too well. My experience drove me to writing a free online hip arthroscopy guide for patients and I designed and completed a randomised controlled trial to look at how preoperative exercises could possibly help recovery from hip arthroscopy, ${ }^{3}$ as part of my Masters Degree research...yes, I am totally a hip geek!

\section{PRESENT DAY}

Eight happy hip years later, in the summer of 2019, I suffered another accident, embarrassingly on my birthday night

Physiotherapy, Physiocure, Leeds, UK

Correspondence to Louise Grant, Physiotherapy, Physiocure, Leeds LS16 7NL, UK; louise.grant@physiocure.org.uk out! I was wearing silly wobbly high heels, when one got stuck in a pavement grate, and I went crashing to the floor. I sustained a elbow fracture, tore my wrist cartilage and badly damaged my left hip again. (Did I mention that I am clumsy?) This time, a THR was on the cards. I had recently been to the London Hip Meeting and good reports were shared there about the robot-assisted THR. My good friend and colleague Hip Surgeon Dr. Jon Conroy had been doing this procedure for a few years and one of my patients that was his very first case in the UK. I had many patients do well with this procedure, which gave me confidence to get the ball rolling.

I practiced what I preach to my patients, keeping up with my muscle activation and non-pain provoking exercises prior to surgery. ${ }^{4}$ I persuaded my teenage son to film me doing my exercises, as well as practical tasks such as setting up my bathroom, so my experience could help other patients. I have watched many hip operations over the years, so I knew full well what would happen in the operation... saws, hammers and bits of me moving in ways you don't want to think about. Whenever those unhelpful thoughts surfaced, I would think about my fabulous mother! She is an amazing advert for the benefits, so I held that positive vision in my thoughts.

On my surgery day, in the autumn of 2019, Dr. Conroy reviewed all the risks and complications. Past patient's faces who have had some of those things happen to them came into my mind like the 'Ghosts of Christmas Past'. I tried my best to block these visions out. In the anaesthetic room, I remember fussing about how I wanted my pillow to support my head on the operating table as they were giving me a sedative; my lower half of my body was already numb. The next thing I remember was waking up in the recovery room. It was like I had blinked, and it was all over!

\section{BACK AT HOME}

I knew from personal and professional experience that there can be a bit of a 'honeymoon period' after surgery. On the ward you feel quite comfortable as the nerve block may not have fully worn off and you have lots of strong medications floating around your system. The pain, swelling and bruising can develop a few

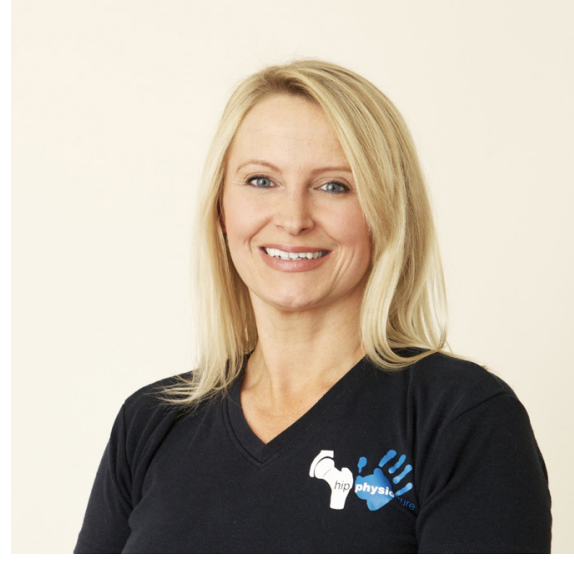

Figure 1 Lou Grant, hip chartered physiotherapist.

days later, as the nerve block wanes and the medications are reduced. My surgeon is a 'no hip restrictions' advocate, but with a swollen painful thigh squatting to the toilet was far more comfortable with a raised toilet seat! I used one for a couple of weeks until sitting on the toilet became pain free, and I was strong enough to do it without modification. I also had some inhibition of my hip flexors postoperatively and I could not lift my leg so I needed to use a 'sock aid' to put my socks on and a 'grabber stick' to put my trousers on. There are many great gadgets available that can help aid independence as you are gradually regaining your movement (figure 2).

\section{USING MY EXPERIENCE TO HELP OTHERS}

My experience as a hip physiotherapist informed my experience as a patient with hip surgery (twice!). I have tried to help educate others through our website (www. physiocure.org.uk).

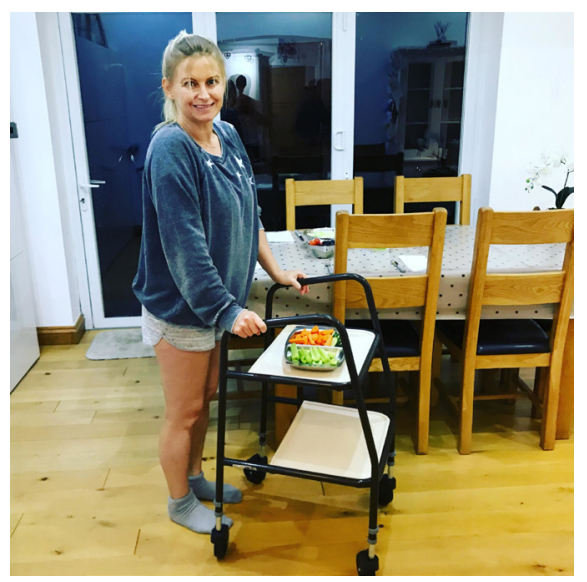

Figure 2 Lou Grant 3 weeks post total hip replacement finding a wheeled trolley helpful in the kitchen. 
There are two points clinicians and patients should always keep in mind.

1. Good communication between the hip surgeon and rehab team is essential, and patients know it. A strong, collaborative interdisciplinary team, like the kind I am fortunate to work with at Physiocure, can facilitate successful outcomes for patients with hip issues.

2. Physiocure hip specialist physical trainer, Tom Higo, refers to rehab as 'slow cooking'. This means not to skip the important fundamental levels, and jump to the exciting, dynamic ones prematurely. Clinicians need to remind patients that we are individuals, whose bodies work differently, with varying tissue healing time frames. Healing is not a race or competition. We must encourage patience in our patients.
Twitter Louise Grant @louisegranthip

Contributors This manuscript has been invited to be written by the BISM as a 'patient voices' article. The article is about the author's patient experience and the author gives full permission for this article to be published. Fine-tuned paper discussed with BJSM editors.

Funding The authors have not declared a specific grant for this research from any funding agency in the public, commercial or not-for-profit sectors.

Competing interests None declared.

Patient consent for publication Not required.

Provenance and peer review Commissioned; internally peer reviewed.

(c) Author(s) (or their employer(s)) 2020. No commercial re-use. See rights and permissions. Published by BMJ.

\section{(A) Check for updates}

To cite Grant L. Br J Sports Med Epub ahead of print: [please include Day Month Year]. doi:10.1136/ bjsports-2019-101899

Accepted 15 March 2020
Br J Sports Med 2020;0:1-2.

doi:10.1136/bjsports-2019-101899

ORCID iD

Louise Grant http://orcid.org/0000-0002-7356-8161

\section{REFERENCES}

1 Sochacki KR, Brown L, Cenkus K, et al. Preoperative depression is negatively associated with function and predicts poorer outcomes after hip arthroscopy for femoroacetabular impingement. Arthroscopy 2018:34:2368-74.

2 Enseki K, Harris-Hayes M, White DM, et al. Nonarthritic hip joint pain. J Orthop Sports Phys Ther 2014;44:A1-32.

3 Grant LF, Cooper DJ, Conroy JL. The HAPI 'Hip Arthroscopy Pre-habilitation Intervention' study: does pre-habilitation affect outcomes in patients undergoing hip arthroscopy for femoro-acetabular impingement? J Hip Preserv Surg 2017;4:85-92.

4 Clode NJ, Perry MA, Wulff L. Does physiotherapy prehabilitation improve pre-surgical outcomes and influence patient expectations prior to knee and hip joint arthroplasty? Int J Orthop Trauma Nurs 2018;30:14-19. 